\title{
Sundhed, Menneske og Samfund
}

\author{
Rikke Sand Andersen
}

Andersen, R. S. (2013). »Boganmeldelse af Sundhed, Menneske og Samfund « Red. Grit Niklasson, Samfundslitteratur 2013. Tidsskrift for Forskning i Sygdom og Samfund, nr. 19, 141-142

Sundhed, Menneske og Samfund er en antologi specielt målrettet undervisningen i samfundsvidenskabelige fag på de sundhedsfaglige professionshøjskoler, som uddanner fysioterapeuter, ergoterapeuter, radiografer, jordmødre, sygeplejersker osv. Formålet med bogen er ifølge redaktøren at give de sundhedsstuderende "mulighed for at tilegne sig en bred samfundsfaglig viden, og at den vil være med til at vække frugtbare politiske, etiske og praktiske drøftelser i undervisningen." Det er min overbevisning, at bogen vil kunne danne grundlag for netop sådanne diskussioner. Det taler særligt til bogens fordel, at den primært, (og jeg vender tilbage til dette forbehold) tager udgangspunkt i en række samfundsvidenskabeligt definerede emneområder, der er relevante for et sundhedsfagligt publikum og ikke i 'sociale problemstillinger', som de defineres indenfor et sundhedsfagligt paradigme ( $f x$ patientinddragelse, health literacy, risikokommunikation).

Antologiens 13 kapitler er skrevet af en række forskere med forskellige faglige baggrunde, der hver især er blevet indbudt til at skrive om netop det, de forsker i. Bogens overordnede samfundsfaglige perspektiv, dækker således over etnologiske teorier om livsformer, sociologiske og antropologiske teorier om stigmatisering, risiko og magt samt mere traditionelle medicinsk sociologiske præsentationer af ulighed i sundhed og sundhedsfremme.

Helt overordnet giver bogen gode introduktioner til de komplicerede samspil, der udfoldes mellem samfundets makrostrukturer som økonomi, diskurser og politik, samt de mikro-processer, der udfolder sig i f.eks. mødet mellem patient og sundhedsprofessionel. Den vil også give de studerende en fornemmelse for det 
forhold, at forskellige sociale og historiske kontekster betinger både sygdomsoplevelser og handlemuligheder.

I Tine Rostgaards kapitel om Velfærdsstaten skitseres den danske velfærdsstats udvikling igennem de sidste 120 år, og vi får en god fornemmelse for, hvordan (kulturelle) forestillinger om, hvad man er berettiget til som borger, ændrer sig i takt med, at velfærdsstatens ydelsesstruktur ændrer sig. Nanna Mik-Meyers kapitel om Magtrelationer i sundhedsarbejdet er en virkelig god introduktion til et kompliceret felt; om den usynlige magt, som den udfolder sig i et tilsyneladende altruistisk felt, og hvorledes den er under indflydelse af overordnede samfundsdiskurser, hvor sundhed er sat i højsædet. Thomas Brecks gennemgang og diskussion af risikobegrebet er også en interessant gennemgang af risikotænkningens historie samt forskellige videnskabelige paradigmers syn på, hvad risiko er for en størrelse. Herudover introduceres vi for Kulturelle sundheds- og sygdomsopfattelser, vi hører om Sundhedsfremme og Folkesundhed, om Ulighed i Sundhed, om Patientperspektiver, om Stigmatisering og om Minoritetsgrupper og Empowerment.

Bogen er et således et velkomponeret bud på en række samfundsvidenskabelige perspektiver på nogle af de temaer og emner, der optager og har relevans for et sundhedsfagligt publikum. Og så tilbage til det forbehold, som jeg introducerede i det ovenstående. Med undtagelse af få kapitler, virker det som om man, fra redaktionel side, har fravalgt mere kritiske - og kritiske i en kritisk refleksiv forståelse af ordet - perspektiver på vor samtids optagethed af sundhed og den symbolværdi, der omgiver alle former for sundhedsrelateret adfærd, relationer og identitetsarbejde. Og velvidende at antologier altid er både tilvalg og fravalg, både af det ønskelige og det mulige, ville det have været interessant med kapitler om etik (som nævnes i bogens introduktion), organisationsteori (hvad er et sundhedssystem eller 'væsen' egentlig for en størrelse?) og teknologi (hvorledes betinger den teknologiske udvikling vores syn på sygdom, behandling, sundhedsprofessionelles kompetencer etc.?).

Disse forbehold til trods synes jeg dog, at bogen er et godt bud på en god og grundig introduktion til samfundsvidenskabelige perspektiver på sundhedsfagligt relevante problemstillinger. 